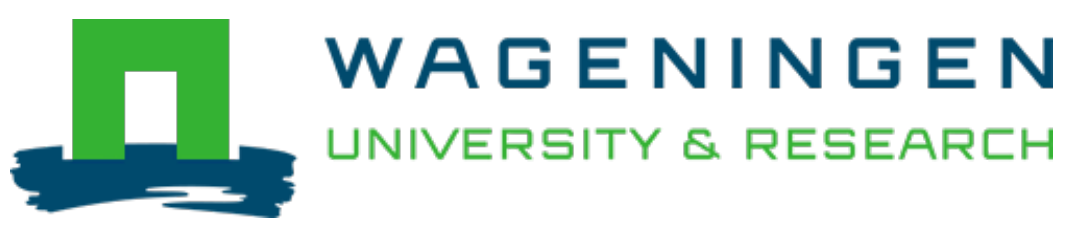

\title{
Costs and Carbon Benefits of Mangrove Conservation and Restoration : A Global Analysis
}

\author{
Ecological Economics \\ Jakovac, Catarina C.; Latawiec, Agnieszka Ewa; Lacerda, Eduardo; Leite Lucas, Isabella; Korys, Katarzyna \\ Anna et al \\ https://doi.org/10.1016/j.ecolecon.2020.106758
}

This article is made publicly available in the institutional repository of Wageningen University and Research, under the terms of article $25 \mathrm{fa}$ of the Dutch Copyright Act, also known as the Amendment Taverne. This has been done with explicit consent by the author.

Article 25 fa states that the author of a short scientific work funded either wholly or partially by Dutch public funds is entitled to make that work publicly available for no consideration following a reasonable period of time after the work was first published, provided that clear reference is made to the source of the first publication of the work.

This publication is distributed under The Association of Universities in the Netherlands (VSNU) 'Article 25fa implementation' project. In this project research outputs of researchers employed by Dutch Universities that comply with the legal requirements of Article $25 \mathrm{fa}$ of the Dutch Copyright Act are distributed online and free of cost or other barriers in institutional repositories. Research outputs are distributed six months after their first online publication in the original published version and with proper attribution to the source of the original publication.

You are permitted to download and use the publication for personal purposes. All rights remain with the author(s) and / or copyright owner(s) of this work. Any use of the publication or parts of it other than authorised under article $25 \mathrm{fa}$ of the Dutch Copyright act is prohibited. Wageningen University \& Research and the author(s) of this publication shall not be held responsible or liable for any damages resulting from your (re)use of this publication.

For questions regarding the public availability of this article please contact openscience.library@,wur.nl 


\title{
Costs and Carbon Benefits of Mangrove Conservation and Restoration: A Global Analysis
}

\author{
Catarina C. Jakovac ${ }^{\mathrm{a}, \mathrm{b}, \mathrm{c}, *}$, Agnieszka Ewa Latawiec ${ }^{\mathrm{a}, \mathrm{b}}$, Eduardo Lacerda ${ }^{\mathrm{a}, \mathrm{b}}$, Isabella Leite Lucas ${ }^{\mathrm{a}}$, \\ Katarzyna Anna Korys $^{\mathrm{a}}$, Alvaro Iribarrem ${ }^{\mathrm{a}, \mathrm{b}}$, Gustavo Abreu Malaguti ${ }^{\mathrm{a}}$, R. Kerry Turner ${ }^{\mathrm{d}}$, \\ Tiziana Luisetti ${ }^{\mathrm{e}}$, Bernardo Baeta Neves Strassburg ${ }^{\mathrm{a}, \mathrm{b}}$ \\ ${ }^{a}$ International Institute for Sustainability, Estrada Dona Castorina 124, 22460-320 Rio de Janeiro, Brazil \\ ${ }^{\mathrm{b}}$ Rio Conservation and Sustainability Science Centre, Department of Geography and the Environment, Pontifícia Universidade Católica, 22453-900 Rio de Janeiro, Brazil \\ ${ }^{\mathrm{c}}$ Wageningen University, Forest Ecology and Forest Management Group, PB 9101, 6700 HB Wageningen, the Netherlands \\ ${ }^{\mathrm{d}}$ Centre For Social and Economic Research On the Global Environment (CSERGE), School of Environmental Sciences, University of East Anglia, Norwich NR47TJ, UK \\ ${ }^{\mathrm{e}}$ Centre for Environment Fisheries \& Aquaculture Science (Cefas), Pakefield Road, Lowestoft, Suffolk NR33 OHT, UK
}

\section{A R T I C L E I N F O}

\section{Keywords:}

Global mangrove map

REDD +

Payment for ecosystem services

Break-even price

Land opportunity cost

Deforestation

Map of worlds

\begin{abstract}
A B S T R A C T
Blue carbon in mangroves represents one of highest values of carbon stocks per hectare, and could play an important role in climate change mitigation. In this study we estimated the carbon prices needed to promote mangrove conservation and restoration under mechanisms of payment for ecosystem services (PES). We mapped the remaining and deforested mangroves across the globe in 2017, and crossed this information with carbon stocks in the biomass and soil and with land opportunity and restoration costs. In accordance with previous studies we found that Southeast Asia holds the largest opportunities for blue carbon programs to support conservation and restoration. Conserving remaining mangroves would avoid the release of up to $15.51 \mathrm{PgCO}_{2}$ to the atmosphere, and could be achieved at carbon prices between 3.0 and 13.0 US\$ per $\mathrm{tCO}_{2}$ for $90 \%$ of remaining mangroves. Restoring mangroves can sequester up to $0.32 \mathrm{PgCO}_{2}$ globally. Carbon prices between 4.5 and 18.0 US\$ per $\mathrm{tCO}_{2}$ could support the restoration of $90 \%$ of deforested mangroves. Such prices, however, may not apply to contexts of high-profit alternative land-uses. In such contexts, the valuation of co-benefits and the combination of carbon-based mechanisms and sustainable management may be a viable pathway.
\end{abstract}

\section{Introduction}

Blue carbon represents carbon sequestered in the biomass and soils of vegetated coastal ecosystems, such as mangrove forests, salt marshes and seagrass beds (McLeod et al., 2011, Fig. 1a). Carbon accumulation in these ecosystems is facilitated by the anoxic environment that minimizes carbon degradation (Alongi, 2012). Additionally, due to trapping suspended matter and associated organic carbon during tidal inundation, the per unit area contribution of coastal ecosystems to longterm carbon sequestration is much greater than that of terrestrial forests (Duarte et al., 2005).

Different from tropical forests that store most of their carbon in the living biomass, mangroves allocate $50-90 \%$ of their carbon pool below ground (Murray et al., 2011). Mangrove soils store on average ( $\pm \mathrm{sd}$ ) $283 \pm 193 \mathrm{tC} \mathrm{ha}^{-1}$ down to $1 \mathrm{~m}$ depth (Atwood et al., 2017) and can reach $1023 \mathrm{tC}$ ha $^{-1}$ down to $3 \mathrm{~m}$ in organic-rich mangroves, like the ones present in Indo Pacific regions (Donato et al., 2011). Such enormous carbon stock makes mangroves an important carbon sink or source depending on its conservation status. Conversion of mangroves to pasture, for example, would release three times more $\mathrm{CO}_{2}$ per hectare to the atmosphere than the conversion of Amazon forests (Kauffman et al., 2016). Therefore, despite their restricted distribution and small extent (Giri et al., 2011; Hamilton and Casey, 2016), mangroves can make a significant contribution to the carbon balance.

Despite the great importance as carbon sinks, blue carbon ecosystems are currently not included in REDD + arrangements and research on payments for ecosystem services for protecting and restoring threatened marine ecosystems and communities that are dependent on mangrove remains scarce (Corbera et al., 2007; Bouillon et al., 2009; Alcorn, 2010). Some reasons for setting such ecosystems aside are related to uncertainty in the extent and carbon stocks and to difficulties in monitoring. Estimates of the extent of mangroves, for example, are highly variable because mangroves are usually located in narrow strips along coastlines. Therefore, remote sensing estimates that consider only

\footnotetext{
* Corresponding author at: International Institute for Sustainability, Estrada Dona Castorina 124, 22460-320 Rio de Janeiro, Brazil.

E-mail address: catacj@gmail.com (C.C. Jakovac).
} 

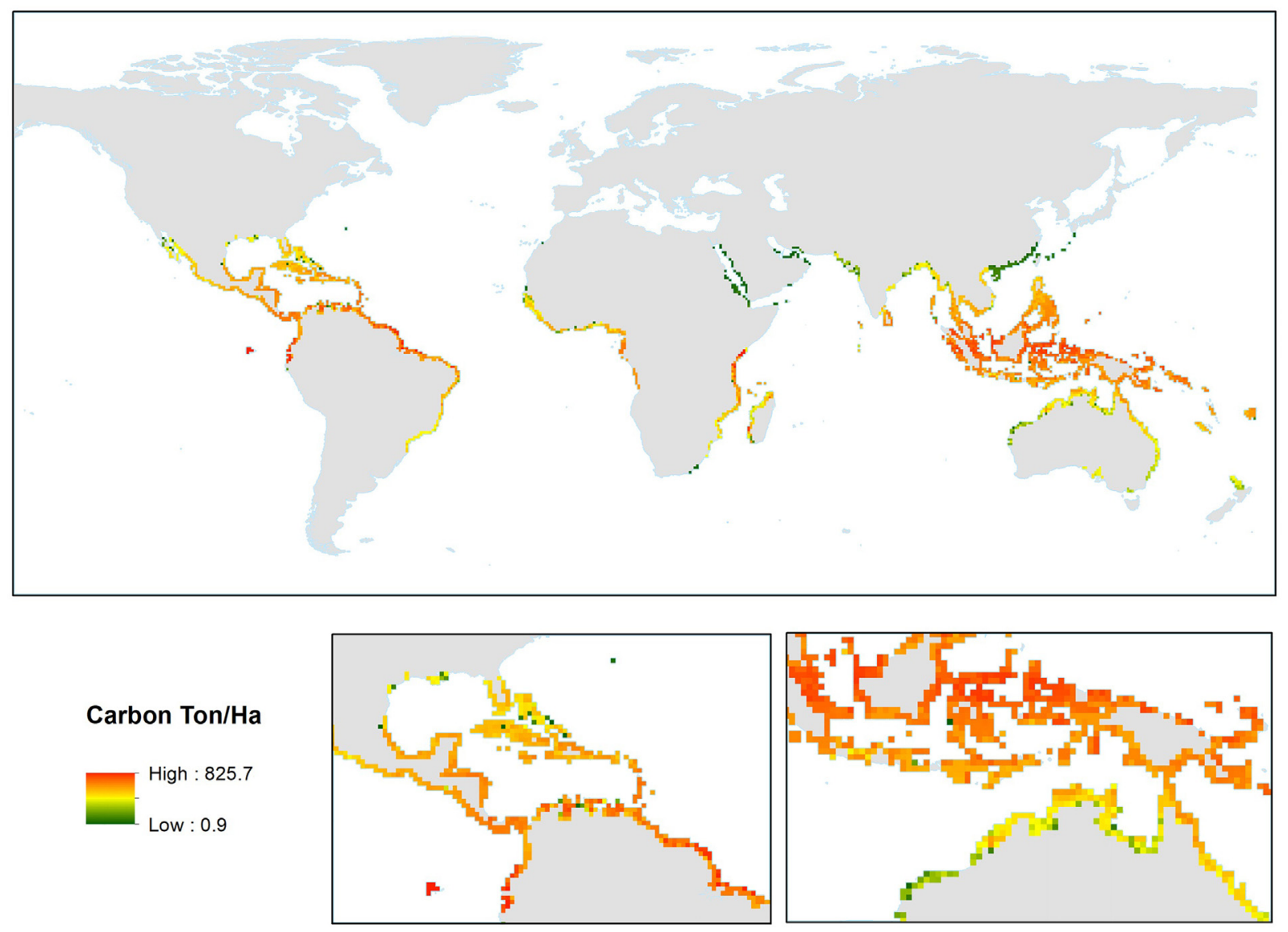

Fig. 1. Mangroves around the world and their contribution to climate change mitigation. Remaining mangroves around the world in the year 2017 (A). Colour gradients show the average carbon stock density in tonnes per hectare, with larger carbon stocks (red colour) close to the equator in South America (B) and Southeast Asia (C). (For interpretation of the references to colour in this figure legend, the reader is referred to the web version of this article.)

presence/absence at the pixel level will usually be overestimated (e.g. Giri et al., 2011) when compared to those that account for continuous data (Hamilton and Casey, 2016). The most recent approach based on high resolution continuous data, estimates that globally mangroves covered 81,000 km² in 2012 (Hamilton and Casey, 2016), which accounts for only $0.2 \%$ of the $39,990 \mathrm{~km}^{2}$ of global forest cover (FAO, 2015). Considering this extent, mangroves are estimated to globally store a total of $4.19 \times 10^{9}$ tC (Atwood et al., 2017; Hamilton and Friess, 2018), with $0.62 \pm 0.13 \%$ stored down to $1 \mathrm{~m}$ depth in soils and $0.29 \pm 0.01 \%$ in the living biomass (Hamilton and Friess, 2018). Although mangroves are present in 105 countries (Hamilton and Casey, 2016), Indonesia, Brazil, Malaysia and Papua New Guinea contain 50\% of the global mangrove extent (Hamilton and Friess, 2018). Such recent estimations were based on satellite data, showing that similar technology applied to monitor terrestrial ecosystems in REDD + systems can be used for updating mangrove gain and loss.

High rates of mangrove loss in recent decades put their carbon stocks at risk. Globally, $137-636 \mathrm{~km}^{2}$ of mangroves are lost annually, which represents $0.16-0.39 \%$ of the ecosystem being lost per year (Hamilton and Casey, 2016). Major causes of mangrove deforestation are urban development, aquaculture, mining, and overexploitation of timber, fish, crustaceans and shellfish (Alongi, 2014). Such deforestation rate represents a potential loss of 2.0-7.5 million tonnes $\mathrm{C} \mathrm{yr}^{-1}$ from mangrove soils, which corresponds to $\sim 7.3-27.5$ million tonnes of $\mathrm{CO}_{2}$ emissions annually (Atwood et al., 2017). Global emissions from soil carbon loss are based on a stock-change approach. Carbon loss from mangrove soils represents $0.6 \%$ of annual $\mathrm{CO}_{2}$ emissions from deforestation worldwide (Atwood et al., 2017), considering that $43 \%$ of $\mathrm{C}$ stocks down to $1 \mathrm{~m}$ in the soil are remineralized after mangrove deforestation and released to the atmosphere at once in the form of $\mathrm{CO}_{2}$ (Murray et al., 2011; Atwood et al., 2017). Other studies estimate that mangrove conversion could release to the atmosphere 84-159 million tonnes of $\mathrm{CO}_{2}$, assuming that between $27.25 \%$ and $90 \%$ of the carbon stored in the soils are lost after deforestation (Siikamäki et al., 2012).

Carbon-based programs for payment for ecosystem services (PES) could help protect mangroves from degradation. Creating financial incentives can be crucial for protecting and restoring threatened marine ecosystems such as mangroves (Warren-Rhodes et al., 2011). Given the importance of blue carbon and the already established carbon-based PES, we focus this study on evaluating, for mangroves ecosystems, what would be the necessary carbon price to compete with alternative land use systems and support mangrove conservation under future REDD + arrangements. Costs of REDD + programs are mainly related to land opportunity costs of alternative land uses potentially replacing mangroves. The lack of a global spatially explicit database on opportunity costs limits the estimation of carbon prices applicable to different contexts. For this reason, carbon prices are usually estimated for specific regions (e.g. Thompson et al., 2017) and it is not clear how applicable those estimated values are to other regions given the great variability in land opportunity costs within and across countries (Yee, 2010). In this study we estimate the land opportunity costs for all mangrove-holding countries, and then calculate and map out carbon break-even prices across the globe. Unlike previous studies that focused only on carbon payments for conserving the remaining mangrove forests based on country averages of mangrove extent and carbon stocks, here we combined the latest high-resolution data on mangroves extent, carbon storage and land opportunity costs, in order to derive high-resolution spatially-explicit estimates of carbon break-even prices for 
mangrove conservation and restoration. To achieve this goal, we updated the most recent mangrove map from 2012 (Hamilton and Friess, 2018 ) to identify the remaining and converted mangroves in the year 2017 and then estimate the potential carbon emission avoided by mangrove conservation as well as the potential carbon sequestration by mangrove restoration. With this approach we make available averages and associated variations of carbon stocks and carbon break-even prices for all mangrove-holding countries. Next, we discuss our global analyses together with published local case studies for having a realistic picture of the feasibility of global prices to support conservation and restoration programs at the regional scale.

\section{Materials and Methods}

To calculate carbon costs to conserve the remaining mangrove forests and to restore the mangrove areas previously converted, we updated the global maps of mangrove areas and carbon stocks and estimated associated land opportunity costs. First, we updated the global map of mangrove area and carbon stocks from Hamilton and Friess (2018) for the year 2012 to the year 2017 based on the identified forest loss by the Global Forest Watch program (Hansen et al., 2013) following the same methodology used by Hamilton and Friess (2018). We chose this carbon stocks estimate over others (e.g. Atwood et al., 2017; Sanderman et al., 2018) because it: (i) accounts for carbon stored in the soils ( $1 \mathrm{~m}$ depth) as well as in the above and below ground biomass; (ii) accounts for continuous mangrove cover instead of presence/absence; and (iii) provides the spatial dataset at a fine resolution. Carbon stocks include above and below ground biomass and soil stocks down to $1 \mathrm{~m}$ depth (for detailed methodology see Hamilton and Friess, 2018). We then estimated the area and the carbon stocks associated to the remaining and deforested mangroves in 2017 by subtracting, respectively, the mangrove area or carbon stocks of the maps for the year 2000 from the updated maps for the year 2017. We worked in the original map resolution of $30 \times 30 \mathrm{~m}$ to build maps for the year 2017 of: (i) the remaining mangroves; (ii) the deforested mangroves; (iii) the conserved carbon stocks; and (iv) the carbon stocks to be restored. Then, we aggregated the cells to $900 \mathrm{~m}$ to improve computer efficiency on calculations of zonal statistics per country. Small deforestation patches may have been omitted after aggregation. In the supplementary material, we summarize all estimates as country averages with the respective standard deviation. All maps produced are available upon request.

Next, we estimated the mean country opportunity costs at a $5 \mathrm{~km}$ resolution based on the average productivity of agriculture and pastures within each mangrove-holding country (Table S1). Agriculture and aquaculture have been the main drivers of mangrove loss and degradation over the last decades (Richards and Friess, 2015; Chowdhury et al., 2017; Giri et al., 2011). In Southeast Asia, for example, 38\% of the converted mangrove area was designated to rice and oil palm agriculture, while $30 \%$ supported aquaculture during the period between 2000 and 2012 (Richards and Friess, 2015). Given the importance of agriculture for mangroves conversion and the unavailability of data on aquaculture productivity for most mangrove-holding countries, we estimated opportunity costs based on agriculture and pasture commodities.

For agriculture, we estimated the opportunity costs for 31 commodities based on the net present value (NPV) of one tonne of produce for 40 years considering a $5 \%$ discount rate. The 31 commodities were selected based on data availability for their current and potential productivity (according to Global Agro-ecological Zones, IIASA/FAO, 2012). Equilibrium-price estimates for each commodity were obtained from the extended data of Sulser et al. (2015) in their SSP2 scenario, obtained from the IMPACT model (Robinson et al., 2015). We used each NPV to convert the values of produced quantity per area (from Global Agro-ecological Zones, IIASA/FAO, 2012) to production value per area in a spatially explicit model. For pastures, we estimated opportunity costs based on the stocking rates provided by the Gridded Livestock of the World v2.0 (Robinson et al., 2015), which were converted from heads per ha to tonnes of produce per hectare using the values of animal yield per country from the IMPACT model (Robinson et al., 2015), and then converted into production value per area based on beef NPV. The opportunity costs for agriculture and pasture were calculated assuming a $20 \%$ margin of profit (following Strassburg et al., 2009). Finally, we calculated the mean opportunity cost (and associated standard deviation) per country (Table S1) as the average of agriculture and pasture opportunity costs weighted by the proportion of each land use with respect to the total anthropic area in the land use and cover map provided by the European Space Agency "Climate Change Initiative" (ESA CCI) for the year, 2015 (available at https://www.esa-landcover-cci. org/?q=node/158).

To calculate the break-even $\mathrm{CO}_{2}$ price for conservation, we estimated the economic value a tonne of $\mathrm{CO}_{2}$ should have (in $\mathrm{US} \$ / \mathrm{tCO}_{2}$ ) to compensate for the potential income from alternative land uses (opportunity costs) for a 40-years period (following Strassburg et al., 2009). We divided the opportunity costs (US\$.ha ${ }^{-1}$ ) by the $\mathrm{CO}_{2}$ avoided-emission $\left(\mathrm{tCO}_{2} \cdot \mathrm{ha}^{-1}\right)$ per pixel. The $\mathrm{CO}_{2}$ avoided-emission is the amount of $\mathrm{CO}_{2}$ that would be released to the atmosphere if the mangrove was deforested, which was calculated based on the total amount of carbon stored in the living biomass and soils (down to $1 \mathrm{~m}$ depth) per hectare in each pixel. To calculate the break-even $\mathrm{CO}_{2}$ price for restoration of already deforested mangroves, we divided the economic costs (US\$), which are the sum of the opportunity costs and the average restoration costs, by the estimated amount of $\mathrm{CO}_{2}$ emitted $\left(\mathrm{tCO}_{2} \cdot \mathrm{ha}^{-1}\right.$ ) from the mangroves lost between 2000 and 2017 (which is the time interval monitored by Hansen et al., 2013). We calculated the average restoration costs for mangroves based on the average restoration cost for all mangrove-holding countries provided by Bayraktarov et al. (2016): US\$ 4368 per hectare.

Estimations on how much carbon is released to the atmosphere after deforestation or sequestered by mangrove soils after restoration remain imprecise. Variations in the depth of soil carbon at risk, the percent of carbon loss from the soil, and the timing of carbon release after landuse-change are dependent on factors such as local environmental conditions, tidal regime and the impact of the alternative land use (Alongi, 2014; Kauffman et al., 2014). As robust estimates to account for such variations at the global scale remain scarce, we estimated carbon amounts and prices considering a range between $25 \%$ and $100 \%$ of the total carbon stock would be lost by deforestation or regained by restoration. For conservation, these scenarios can also be used to represent avoided carbon emissions at different management levels. We calculated the $25 \%$ and $100 \%$ scenarios for all carbon-related estimations.

\section{Results}

\subsection{Lost and Remaining Mangrove Area and Carbon Stocks}

The remaining mangroves in 2017 covered an area of $81.792 .93 \mathrm{~km}^{2}$ and were estimated to hold a total of 4,231,311,055 t of carbon (4.23 PgC) in its biomass and soil (Table S2). Such carbon stocks in mangroves are largely concentrated in 25 countries, which host $90 \%$ of the global remaining mangroves (Fig. 1; Table 1). Conserving these mangroves would avoid the emission of between $3,878,701,800$ and $15,514,807,200 \mathrm{tCO}_{2}\left(3.88-15.51 \mathrm{PgCO}_{2}\right)$ if $25 \%$ and $100 \%$ of the stored carbon in the living biomass and soils would be released to the atmosphere, respectively. Almost half of this global carbon stock (48\%) would be conserved in Asia alone (Fig. 2).

From 2000 to 2017, the globe lost $1540.22 \mathrm{~km}^{2}$ of mangroves, emitting up to $320,309,909 \mathrm{t} \mathrm{CO}_{2}\left(0.32 \mathrm{PgCO}_{2}\right)$ to the atmosphere (Table S2). Only 15 countries were responsible for $99 \%$ of greenhouse gas (GHG) emissions from mangroves deforestation (Table 1). Estimates on the deforested mangrove area per country are provided in Table S2. 


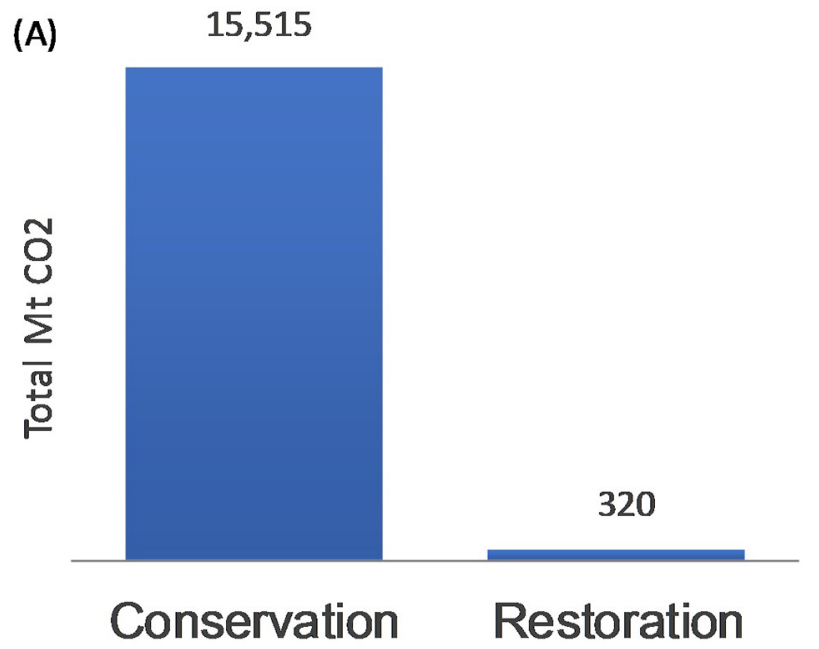

(B)
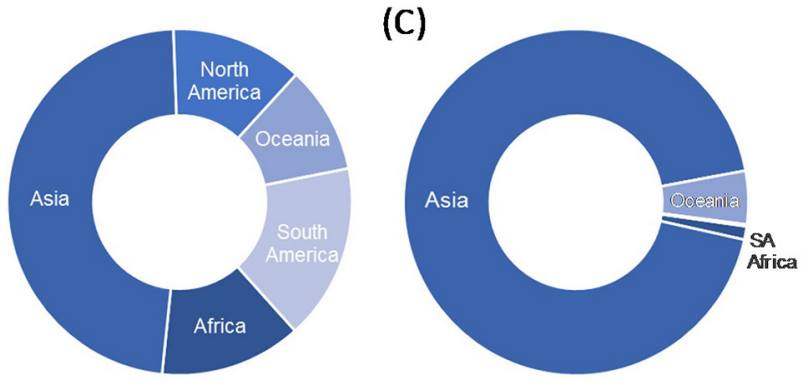

CO2 avoided emissions

$\mathrm{CO} 2$ to be sequestred by mangrove conservation by mangrove restoration

Fig. 2. Contribution of mangrove conservation and restoration to climate change mitigation across continents. Total amounts of $\mathrm{CO}_{2}$ avoided emissions by the conservation of remaining mangroves, and to be sequestered by mangrove restoration (A); Contribution of continents to $\mathrm{CO}_{2}$ avoided emissions if they conserve the remaining mangroves (B); Contribution of continents to $\mathrm{CO}_{2}$ sequestration by restoration of deforested mangroves (C).

Deforestation patterns in mangroves are different from terrestrial tropical forests where large patches of forests are deforested at once. In mangroves, deforestation often happens at small scale because mangroves often cover narrow fringes of coastlines. It is possible, therefore, that small patches of deforestation were omitted during spatial data aggregation, leading to low restoration-need values for some countries like Brazil, for which we estimated zero restoration need (Table S2). Such limitation, however, do not affect estimates for the most important countries for conservation and restoration of mangroves, which area estimates are in accordance with previous studies (Hamilton and Casey, 2016; Hamilton and Friess, 2018).

Restoring those mangroves would remove from the atmosphere between 80,077,477 and 320,309,909 $\mathrm{tCO}_{2}\left(0.08-0.32 \mathrm{PgCO}_{2}\right)$ in the scenarios of $25 \%$ and $100 \%$ carbon sequestration, respectively. The need for mangrove restoration is also concentrated in Asia, where $94 \%$ of the potential carbon sequestration could be realized (Fig. 2).

\subsection{Break-Even Carbon Prices for Conservation and Restoration}

Our results indicate that carbon-based mechanisms have the potential to be a powerful tool to stimulate mangrove conservation and promote carbon sequestration through mangrove restoration globally. Due to the very large carbon densities in mangrove soils (Table S2), land opportunity and restoration costs can be compensated for by relatively low carbon prices (Table 2, Fig. 3, Fig. 4).
Table 1

Countries responsible for $90 \%$ of GHG emissions from mangrove deforestation between 2002 and 2017, and respective $\mathrm{CO}_{2}$ emissions estimated based on the assumption that between $25 \%$ and $100 \%$ of the carbon stored in the living biomass and down to $1 \mathrm{~m}$ depth into the soils of mangroves have been lost to the atmosphere.

\begin{tabular}{llll}
\hline Country & $\begin{array}{l}\text { Lost mangrove area } \\
\text { (ha) }\end{array}$ & $\begin{array}{l}\text { Emissions } \\
\left(\mathrm{tCO}_{2}\right)\end{array}$ & Emissions $\left(\mathrm{tCO}_{2}\right)$ \\
\cline { 2 - 4 } & & $25 \%$ scenario & $100 \%$ scenario \\
\hline Indonesia & 70,766 & $38,038,341$ & $152,153,362$ \\
Malaysia & 40,191 & $21,155,522$ & $84,622,088$ \\
Myanmar & 12,830 & $5,753,786$ & $23,015,145$ \\
Philippines & 4937 & $2,599,727$ & $10,398,908$ \\
Papua New Guinea & 4627 & $2,328,371$ & $9,313,482$ \\
Thailand & 3627 & $1,670,081$ & $6,680,323$ \\
Malaysia & 2924 & $1,642,487$ & $6,569,946$ \\
Vietnam & 3394 & $1,622,231$ & $6,488,924$ \\
Palau & 2380 & $1,419,444$ & $5,677,774$ \\
Cambodia & 2264 & $1,014,734$ & $4,058,934$ \\
India & 2047 & 920,400 & $3,681,602$ \\
Brunei Darussalam & 1039 & 459,640 & $1,838,560$ \\
Kenya & 829 & 436,945 & $1,747,779$ \\
Mozambique & 617 & 257,455 & $1,029,819$ \\
Australia & 525 & 224,882 & 899,529 \\
\hline
\end{tabular}

In Fig. 3 we present the estimated carbon break-even price, which is the carbon prices that makes carbon revenues equals to the average opportunity costs in each country, and the corresponding mangrove area that could be conserved at that given carbon price. Carbon prices between US\$ 3.0 and 13.0 per $\mathrm{tCO}_{2}$ would be enough to conserve $90 \%$ of global mangroves in the $100 \%$ and $25 \%$ carbon-conservation scenarios (Fig. 3, Table S2). To restore $90 \%$ of the deforested mangroves, carbon prices between US\$ 4.5 and 18.0 per $\mathrm{t} \mathrm{CO}_{2}$ would be required considering a carbon-recovery potential of $100 \%$ and $25 \%$, respectively (Fig. 3). These carbon prices translate into potential payments of US\$ 1467-28,099 per ha for conservation and US\$1669-31,961 per ha for restoration in the $100 \%$ and $25 \%$ scenarios for the timeframe of 40 years, given that a hectare of mangrove stores on average $1799 \pm 376 \mathrm{tCO}_{2}$ (Table S2).

In Fig. 4, we present the potential carbon break-even prices for conserving mangroves in the 25 countries that hold $90 \%$ of the world's mangrove area. United states, Australia and India show the highest carbon prices, while African countries show the lowest. Indonesia and Brazil show the largest share of mangrove area to be conserved and this could be achieved by carbon prices between US\$ 3.0 and 11.0 per $\mathrm{tCO}_{2}$ in the $100 \%$ and $25 \%$ scenarios (Fig. 4). For most countries, a carbon price of US\$ 6-10 US per $\mathrm{tCO}_{2}$ would be enough to support mangrove conservation (Table 2, Fig. 4).

\section{Discussion}

\subsection{Break-Even Carbon Prices for Mangrove Conservation and Restoration}

Our results show that relatively low carbon prices would be required to compensate for the opportunity costs from most land uses threatening mangroves. Our carbon price estimates for mangrove conservation (3-13 US\$/tCO2) are in accordance with previous global carbon break-even estimates of 4-12 US\$/tCO2 (Yee, 2010; Siikamäki et al., 2012; Thompson et al., 2014, 2017), which are the lowest within coastal ecosystems (Murray et al., 2011). These values also compare favourably to those estimated for tropical forests, which varies between 35 and 51 US\$/ $\mathrm{tCO}_{2}$ (Warren-Thomas et al., 2018). Supporting mangrove restoration would require higher carbon prices (4.5 and 18 US $\$ / \mathrm{tCO}_{2}$ ) than conservation, but the estimated financial gain per hectare (Table S2) still surpasses the restoration costs in many regions. Among coastal and marine ecosystems, mangrove restoration is usually the 


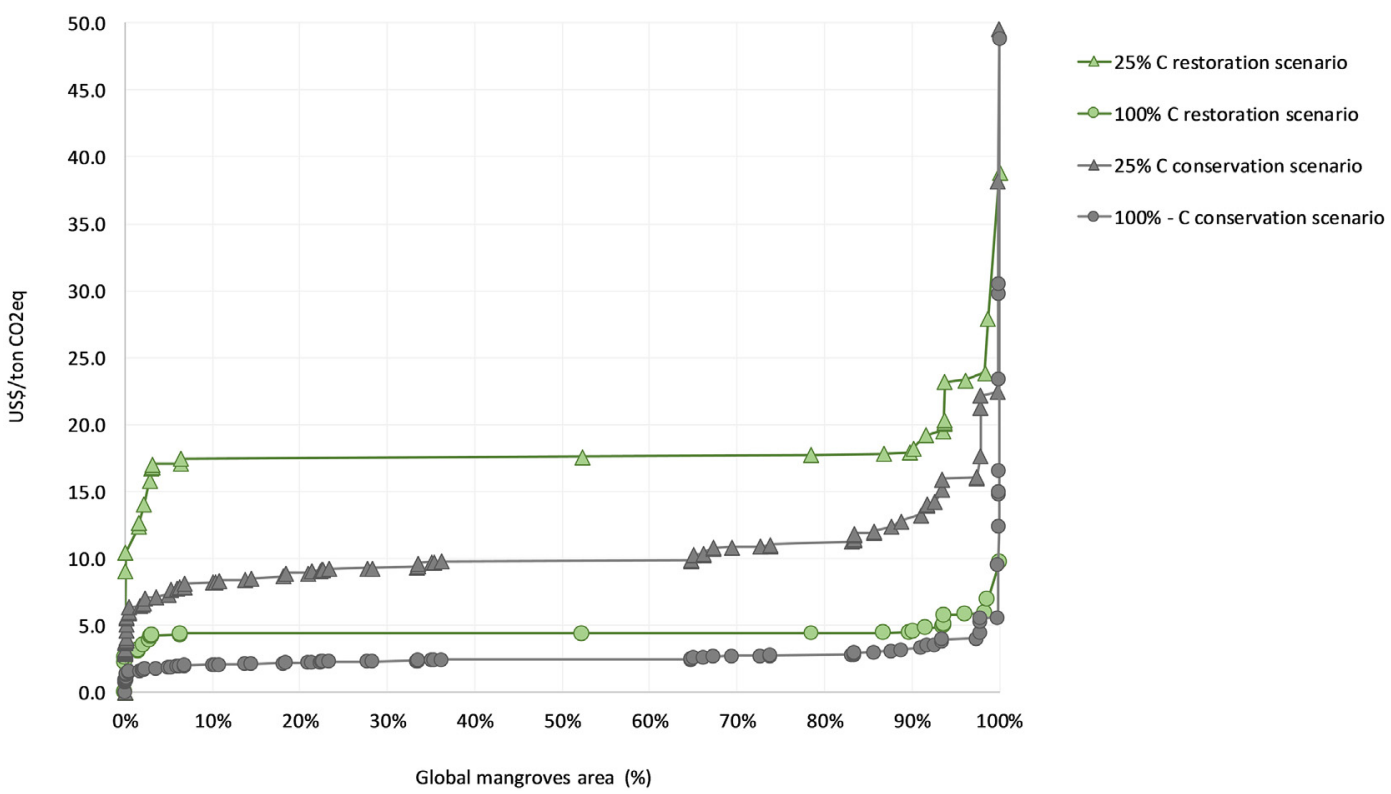

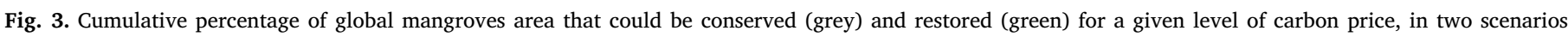

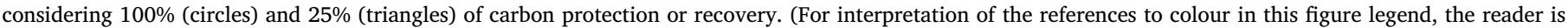
referred to the web version of this article.)

least expensive and the one that embraces larger areas (Bayraktarov et al., 2016), holding the potential for sequestering large amounts of carbon under the support of carbon-based mechanisms. This is possible due to the high density of carbon stocks in mangroves, which allows for low $\mathrm{CO}_{2}$ prices to yield high revenues per hectare.

Both land opportunity costs and restoration costs, however, can vary widely across regions, depending on the alternative land uses, logistical aspects and degradation level (Bayraktarov et al., 2016). Such variation in costs is not fully accounted for in our analysis due to the unavailability of estimates at the regional level for the main costs involved. We have, therefore, reviewed case studies on incentives for mangrove conservation and restoration to access carbon prices and the costs for land opportunity and restoration in mangroves in order to evaluate the applicability and limitations of our estimates. Among the 42 studies we found on incentives for conservation and/or restoration of mangroves, only six presented mechanisms of PES and only four explicitly stated economic values for carbon or other ecosystem services (Thompson et al., 2014, 2017; Lal, 2003; Cormier-Salem and Panfili,

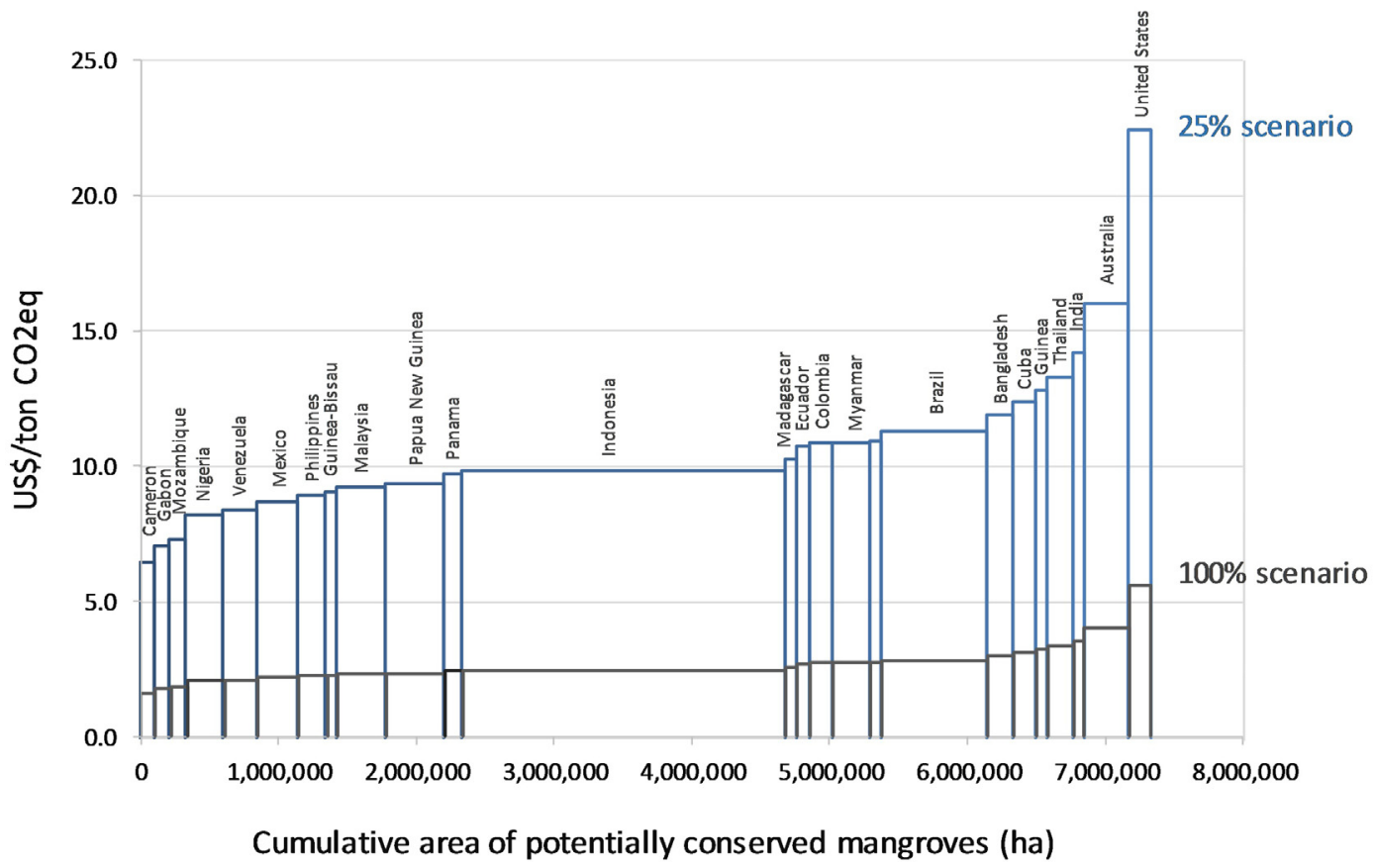

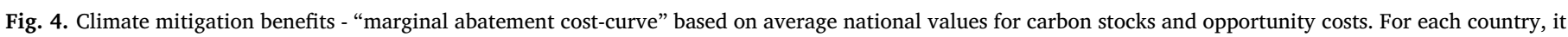

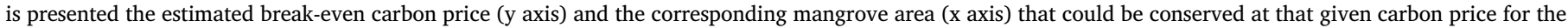

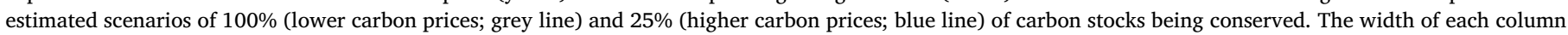

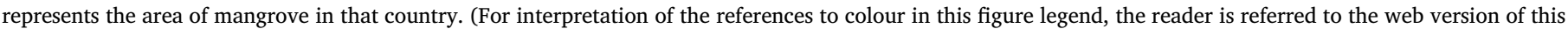
article.) 
2016). Most studies focused on Southeast Asia and on aquaculture probably because it has been expanding and becoming an increasing threat to mangroves at the same time as an important source of income for coastal dwellers in the region (Walters et al., 2008). Southeast Asia deserves special attention as it holds the greatest potential for carbon sequestration and avoided emissions by mangrove conservation and restoration, followed by South America (Fig. 2).

The conversion of mangroves to milkfish aquaculture could release 1466.7 tCO2.ha ${ }^{-1}$ over 25-years, and the volume of $\mathrm{CO}_{2}$ that would be reliable under reduced emissions projects would be $61.84 \mathrm{tCO}_{2} \mathrm{e}$ ha $^{-1} \mathrm{yr}^{-1}$ (Thompson et al., 2014). In the Philippines, for example, fishery and aquaculture, particularly of milkfish (Chanos chanos), contribute to $2.4 \%$ of the countries' GDP and is the main source of income to many landowners (Hoegh-Guldberg et al., 2009). There, an estimated carbon price of 5-12 US $\$ / \mathrm{tCO}_{2}$ could compensate for the annual profits from milkfish aquaculture (Thompson et al., 2014). A related study found that carbon credit prices of 4-10 US\$/tCO2 would contribute an additional 2.3-5.8\% annual income at the village level (Thompson et al., 2017). Such carbon prices could cover opportunity costs for aquaculture also in regions such as Thailand, where shrimp farming has been the main threat to mangrove conservation as well as the main source of income to coastal inhabitants since the 1980s (Yee, 2010). Malik et al. (2015) estimated a NPV of commercial aquaculture in Indonesia to be 1227 US $\$$ /ha for a period of 10 years with a $10 \%$ discount rate, which would be around 3408 US $\$ /$ ha when adjusted to the same methodology we used. Such opportunity costs could be covered by the carbon break-even prices we estimated for Indonesia (2.46-9.85 US $\$ / \mathrm{CO}_{2}$; Table S2), which weighted by the carbon density in those mangroves would yield 5068-20,275 US\$/ha in a 40-year period (Table S2).

Such values, however, may not cover the land opportunity costs of the whole range of production systems and farming practices in the country. Yee, 2010 estimated the yield from shrimp farming in Thailand to vary from US $\$ 744 /$ ha to US $\$ 36,000 /$ ha, which would translate into carbon break-even prices between $\$ 3.22 / \mathrm{tCO}_{2}$ and $\$ 156.00 / \mathrm{t} \mathrm{CO}$, with an average of US\$27.00/t $\mathrm{CO}_{2}$ needed to compensate for the opportunity costs (Yee, 2010). In another context in the same country, however, Lal (2003) reported carbon payments at the level of 86 US $\$ /$ ha/year, which was higher than the income generated by fishing (8$63 \mathrm{US} \$ / \mathrm{ha} / \mathrm{yr}$ ), and lower than the damage generated by erosion after mangrove deforestation (2990US\$/ha/yr).

These case studies suggest, therefore, that carbon prices estimated in this study are applicable to most areas with low to average profits. Although we couldn't include aquaculture opportunity costs in our analyses, the $25 \%-100 \%$ scenarios provide a range of prices that can apply to most contexts. In cases of high-profitable alternative land uses, such as some aquaculture systems, carbon alone may not be able to cover land opportunity costs. Indonesia, for example, holds the highest mangrove deforestation rates (Table 1 ) and is experiencing an expansion of shrimp and fish aquaculture (Herr et al., 2017). It remains unknown, however, the extension of high profitable aquaculture systems across mangroves in the world. Detailed assessments of regional variations in current land opportunity costs in mangroves is, therefore, essential to allow for quantifying and mapping where low, average and high carbon prices are applicable.

In contexts where carbon payments are not enough to compete with high-profit activities, other mechanisms may be needed, such as a combination of sustainable land-use practices and carbon-based PES programs, the inclusion of other ecosystem services in PES programs, and the inclusion of provisioning services as active part of local income, which indirectly benefit from mangrove conservation. Co-benefits and combinations of different ecosystem services in PES programs are rarely accounted for in break-even prices calculations and should be given higher attention.

\subsection{Beyond Carbon: Co-Benefits from Mangrove Conservation and Restoration}

Carbon sequestration is only one among several paramount ecosystem services provided by mangroves. A range of regulating services (such as storm protection, reduction of erosion; water quality maintenance and climate regulation), provisioning services (accountable for subsistence and commercial fisheries and traditional medicines), cultural services (e.g. tourism and recreation; spiritual and sacred sites) and supporting services (nutrient cycling; nursery habitats) are provided by mangroves (UNEP-WCMC, 2006; Bayraktarov et al., 2016). Ecosystem services with local effects, such as protection against coastal disasters and provisioning of products, are perceived by inhabitants of coastal areas as more meaningful than climate-related services (e.g. carbon) (Thompson and Friess, 2019). The valuation of these services and the implementation of PES mechanisms to safeguard them, however, are less advanced than those related to carbon. Other services beyond carbon should, therefore, be given more attention as complementary services in blue carbon programs.

We found a few examples in the literature where ecosystem services other than carbon from mangroves have been valuated. Mangroves can indirectly yield up to US\$ $37,500 / \mathrm{ha}^{\prime}$ yr serving as nurseries for fisheries, while its deforestation and conversion to shrimp farming would yield only US $\$ 1220 / \mathrm{ha}^{\prime} \mathrm{yr}$ in Buri (Sala et al., 2013). In this same region, an earthquake devastated large tracts of mangroves and fishers lost 708 US $\$ /$ person $^{\prime} \mathrm{yr}$ as a consequence of the reduction in fishery productivity (Warren-Rhodes et al., 2011). In the Salomon Islands, the income from mangroves' goods and services has been estimated to represent $38-160 \%$ of annual household incomes (US\$ 345-1501) (Warren-Rhodes et al., 2011). Products such as mangrove propagules, timber for construction, firewood, and fishes were the most important mangrove services cited by local people.

Such services provided by mangroves to local dwellers, either directly through products or indirectly through the protection of coastal areas, can be incorporated in conservation and restoration programs to improve their effectiveness and the returns to local people. For example, reducing the risks of natural disasters and restoring ecosystems strongly damaged by typhoons, storms or civil war were goals of different PES programs for mangrove conservation and restoration in Vietnam (Tri et al., 1998; Tai et al., 2009; Powell et al., 2011a; Hanson et al., 2015). Among the different approaches used in the country, the most successful were those that implemented combined actions for poverty alleviation, market integration, and diversification of livelihoods as part of the compensation for mangroves sustainable management. Such actions ultimately contributed to improve households' resilience (Powell et al., 2011b) and to double the village's income compared to aquaculture, in the long term (Hanson et al., 2015). Such examples show that mangroves conservation and restoration can generate larger benefits than alternative land uses by concomitantly providing direct yield and reducing costs related to climate disasters.

Another approach, taken in the Socio Manglar Program in Ecuador under a blue carbon scheme, provided direct financial incentives for the coastal communities in return for the restoration and sustainable management of mangroves (Herr et al., 2017). The incentive was calculated based on two criteria: (i) a fixed annual payment varying from US $\$ 7000$ for mangrove areas smaller than $100-500$ ha to US\$ 15,000 for areas larger than 1000 ha, and (ii) a variable amount that depended on the size of the area under concession (US\$ ha/year). The intensive participatory process resulted in a high rate of participation of local people, which led the mangrove area covered by the programme to double within one year (Herr et al., 2017). On a different experience, a REED + program in Senegal supported mangrove restoration through the remuneration of local people to gather propagules from one mangrove species (Rhizophora mangle), paying US $\$ 2$ - US $\$ 3.2$ for $50 \mathrm{~kg}$ bag of propagules and limited to US $\$ 418$ per family (Cormier-Salem and Panfili, 2016). This program was largely criticised by its top down 
Table 2

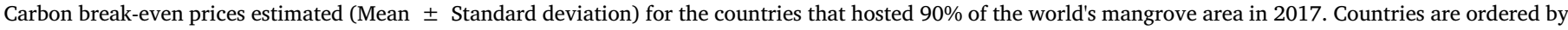

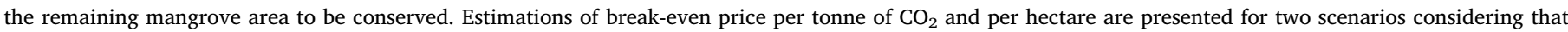

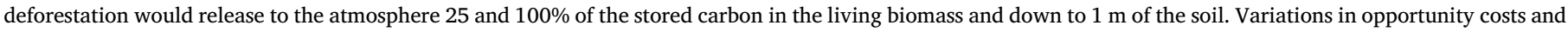

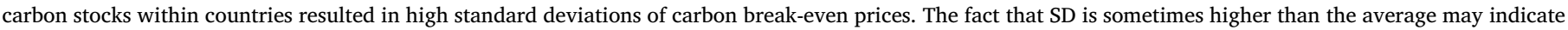

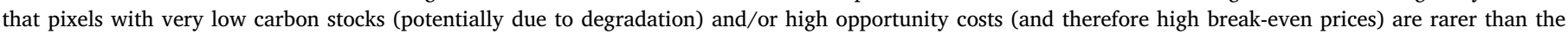
majority of the estimates.

\begin{tabular}{|c|c|c|c|c|c|c|c|c|}
\hline \multirow[t]{4}{*}{ Country } & \multicolumn{4}{|c|}{ Break-even price } & \multicolumn{4}{|c|}{ Break-even price } \\
\hline & \multicolumn{4}{|c|}{$\left(\mathrm{US} \$ / \mathrm{tCO}_{2}\right)$} & \multicolumn{4}{|l|}{ (US\$/ha) } \\
\hline & \multicolumn{2}{|c|}{$25 \%$ scenario } & \multicolumn{2}{|c|}{$100 \%$ scenario } & \multicolumn{2}{|c|}{$25 \%$ scenario } & \multicolumn{2}{|c|}{$100 \%$ scenario } \\
\hline & Mean & SD & Mean & $\mathrm{SD}$ & Mean & SD & Mean & SD \\
\hline Indonesia & 9.8 & 13.0 & 2.5 & 3.2 & $20,275.0$ & $26,681.4$ & 5068.8 & 6670.3 \\
\hline Brazil & 11.3 & 36.8 & 2.8 & 9.2 & $21,219.9$ & $69,187.6$ & 5305.0 & $17,296.9$ \\
\hline Papua New Guinea & 9.4 & 13.4 & 2.3 & 3.3 & $18,680.0$ & $26,672.8$ & 4670.0 & 6668.2 \\
\hline Malaysia & 9.3 & 3.4 & 2.3 & 0.8 & $18,824.4$ & 6816.1 & 4706.1 & 1704.0 \\
\hline Australia & 16.0 & 14.3 & 4.0 & 3.6 & $27,198.2$ & $24,210.1$ & 6799.5 & 6052.5 \\
\hline Mexico & 8.7 & 25.6 & 2.2 & 6.4 & $15,607.6$ & $45,979.4$ & 3901.9 & $11,494.8$ \\
\hline Nigeria & 8.2 & 3.3 & 2.1 & 0.8 & $14,874.7$ & 5919.4 & 3718.7 & 1479.9 \\
\hline Myanmar & 10.9 & 6.5 & 2.7 & 1.6 & $18,280.8$ & $10,940.4$ & 4570.2 & 2735.1 \\
\hline Venezuela & 8.4 & 12.2 & 2.1 & 3.1 & $15,376.5$ & $22,391.6$ & 3844.1 & 5597.9 \\
\hline Philippines & 8.9 & 9.6 & 2.2 & 2.4 & $16,777.4$ & $18,123.1$ & 4194.4 & 4530.8 \\
\hline Thailand & 13.3 & 7.1 & 3.3 & 1.8 & $24,198.1$ & $12,870.1$ & 6049.5 & 3217.5 \\
\hline Bangladesh & 11.9 & 5.2 & 3.0 & 1.3 & $18,167.3$ & 7940.7 & 4541.8 & 1985.2 \\
\hline Colombia & 10.9 & 15.8 & 2.7 & 3.9 & $20,289.2$ & $29,494.9$ & 5072.3 & 7373.7 \\
\hline Cuba & 12.4 & 19.9 & 3.1 & 5.0 & $22,645.9$ & $36,290.6$ & 5661.5 & 9072.7 \\
\hline United States & 22.4 & 32.9 & 5.6 & 8.2 & $38,944.2$ & $57,107.2$ & 9736.0 & $14,276.8$ \\
\hline Panama & 9.7 & 39.2 & 2.4 & 9.8 & $20,184.6$ & $81,236.6$ & 5046.1 & $20,309.2$ \\
\hline Mozambique & 7.4 & 5.4 & 1.8 & 1.4 & $12,639.2$ & 9294.4 & 3159.8 & 2323.6 \\
\hline Cameroon & 6.5 & 3.1 & 1.6 & 0.8 & $11,768.4$ & 5702.8 & 2942.1 & 1425.7 \\
\hline Gabon & 7.1 & 5.8 & 1.8 & 1.5 & $14,666.4$ & $12,019.9$ & 3666.6 & 3005.0 \\
\hline Ecuador & 10.8 & 7.5 & 2.7 & 1.9 & $25,129.2$ & $17,452.9$ & 6282.3 & 4363.2 \\
\hline Malaysia & 11.0 & 4.7 & 2.7 & 1.2 & $22,223.8$ & 9607.9 & 5556.0 & 2402.0 \\
\hline Madagascar & 10.3 & 4.4 & 2.6 & 1.1 & $18,593.9$ & 7903.0 & 4648.5 & 1975.7 \\
\hline Guinea & 12.8 & 4.2 & 3.2 & 1.0 & $21,911.7$ & 7160.4 & 5477.9 & 1790.1 \\
\hline India & 14.2 & 9.1 & 3.6 & 2.3 & $23,700.6$ & $15,160.7$ & 5925.1 & 3790.2 \\
\hline Guinea-Bissau & 9.1 & 5.1 & 2.3 & 1.3 & $14,839.2$ & 8306.2 & 3709.8 & 2076.5 \\
\hline
\end{tabular}

approach and ecological flaws. The collection of propagules instead of production of saplings can negatively impact the dynamics of remaining mangrove forests. Also, the company claimed control over the replanted areas for at least 30 years - the duration of the REDD + contract -, which was perceived as 'green grabbing' in detriment of the local traditional users and owners of these territories (Cormier-Salem and Panfili, 2016). This is an example of how a REDD + program can be disputable in terms of legitimacy and effectiveness (Ndour et al., 2011) and may actually jeopardize the wellbeing of local populations. Participatory planning and implementation, including different stakeholders is, therefore, a crucial aspect of successful PES programs (Thompson and Friess, 2019).

Although ecosystem services provided by mangrove can represent a significant source of income for local people, its unsustainable management can be a serious threat to mangrove conservation. The reduction in the impact of production activities requires the development and adoption of technologies that increase productivity and reduce side-impacts. An eco-farming aquaculture system in Guangxi, for example, allows implementation of fishery systems without cutting mangrove trees (Romañach et al., 2018). The system is based on a network of underground tubes and pipes in between mangrove roots that augments availability of habitat for fishes. The system generated between 27,000 and 45,000 US\$ per hectare per year in fish production (Romañach et al., 2018). Systems that do not require large transformations of mangrove carbon stocks could be combined with PES programs for carbon or other ecosystem services. Our estimates for scenarios of 25 to $100 \%$ avoided carbon emissions provides a range of carbon break-even prices that could be applied to contexts of different management levels.

Next to sustainable management systems, practices and technologies that improve the profitability of mangrove products should be pursued. Fishers often have to deal with product losses due to constraints such as accessibility to markets, poor infrastructure and unreliable access to electricity. Smoking fishes using firewood harvested from mangroves is a common practice to improve the return from fishery in West-Central Africa where there are no other means of preservation (Eyabi, 1995; Feka and Manzano, 2008; Feka et al., 2009). Harvesting firewood often results in the degradation of mangrove forests. Improved fuel-efficiency systems for fish smoking have been implemented in the Douala-Edea Wildlife Reserve in Cameroon (Feka et al., 2009), reducing the volume of firewood extracted to about $50 \%$ and increasing the systems efficiency in about $70 \%$ compared to traditional systems, with no reduction in fish quality. It was estimated that $41 \%$ of mangroves can be conserved annually in the study sites with the adoption of improved smoke system. The implementation of similar systems in India contributed to reduce firewood consumption, to improve working conditions for women and children in special, and to alleviate poverty (Shastri et al., 2002). Such systems are expensive, though, and inaccessible to many communities (Ajonina and Eyabi, 2002; Feka et al., 2009). Financial incentives and carbon credit schemes can be a pathway to support the development, spread and adoption of new technologies and management practices that reduce mangrove degradation and foster mangrove conservation while helping alleviate poverty (Chong, 2006, Alongi and de Carvalho, 2008). In Indonesia, the sustainable management of mangroves contributed to the reduction of 26-41\% GHG emissions at the national level (Murdiyarso et al., 2015). Therefore, where payment for exclusive mangrove conservation is too costly or where livelihoods are highly dependent on mangrove products, increasing the efficiency of mangrove-dependent activities is paramount for holding back mangrove degradation and fostering 


\section{mangrove restoration.}

Altogether, case studies show that incorporating other ecosystem services beyond carbon can importantly increase the profitability and effectiveness of mangrove restoration and conservation. A study on stakeholders' preferences for PES programs revelled that the motivation of local inhabitants for participating in PES programs was beyond the financial gains and included land tenure security and long-term ecological benefits (Thompson and Friess, 2019). Participatory planning and implementation including different stakeholders is, therefore, a crucial aspect of successful PES programs (Thompson and Friess, 2019). Additionally, these experiences emphasize that a successful program must embrace forms of increasing livelihood resilience through investments in infrastructure, the facilitation of new value chains, the adoption of sustainable practices and technologies and especially the involvement of stakeholders in the design, coordination and management of PES programs (Hanson et al., 2015; Thompson and Friess, 2019).

\subsection{Constraints and Financial Mechanisms for Blue Carbon Programs}

Our and previous studies suggest that relatively low carbon prices could support mangrove conservation and restoration. However, blue carbon programs are rarely implemented and mangroves are rapidly being replaced by alternative land uses. The successful implementation and maintenance of Blue carbon programs is often constrained by lack of enforcement, human and financial resources, reduced governance, and conflicts with local peoples' interests (Herr et al., 2017). Additionally, the biophysical characteristics of mangroves as well as the large variation in socio-economical contexts may require a portfolio of blue carbon mechanisms that suits different contexts. Our global analysis combing high resolution maps of carbon stocks, vegetation cover, and opportunity costs captures a large variability of carbon prices across mangroves in the world (Fig. 1). This result, together with our estimates at different carbon-protection/restoration scenarios can help support the design of country-specific mangrove protection programs, which can be fully based on carbon pricing or combined with sustainable management and other PES programs.

Despite a few exceptions, such as the Sundabans in India, mangroves cover thin strips along the coasts (Fig. 1) and its deforestation and degradation happens in scattered patches (Hamilton and Friess, 2018; this study). In such contexts, small-scale community-based projects can be more successful than large-scale top-down investments. For small-scale programs, the voluntary carbon market may be more accessible compared to other markets, due to lower requirements and costs in the project implementation process (Wylie et al., 2016). Programs based on voluntary markets can accommodate government PES programs as well as community-based production.

Another important aspect is that many mangroves are public or communal land, which is usually an issue to determine who will receive the values for restoring or conserving them (Barnes, 2014; Wylie et al., 2016). Active participation of different sectors of society, therefore, needs to be incorporated in all stages of mangroves PES programs to guarantee that key issues directly and indirectly related to management and commercialization are tackled. There is evidence that communitybased mangrove management stimulate a more sustainable use of the land (Romañach et al., 2018). This is especially relevant in restoration initiatives, where long-term efficiency is often strongly dependent on local dwellers (Thompson and Friess, 2019).

In regions where the profitability of alternative land uses is too high, carbon financing mechanisms alone will likely not be effective. Therefore, it is essential that co-benefits, sustainable management and innovative low-impact practices enter the blue carbon agenda. Carbon provides a measurable benefit to support the design and monitoring of financial mechanisms, but for blue carbon to be efficient, it must allow combinations with other ecosystem services (Strassburg et al., 2012) and must accommodate context-dependent solutions co-developed with local people's participation (Herr et al., 2017).

The realization of Blue Carbon potential, though, relies on global investments that relies on appropriate funding mechanisms. Blended finance initiatives that cooperatively groups private, public and philanthropic capital are seen as a promise for blue carbon (Vanderklift et al., 2019). In a blended finance system, publicly-funded options would improve the risk and return relations of blue carbon activities, making these projects more competitive (Clark et al., 2018; Vanderklift et al., 2019). Other traditional and innovative financial tools are traditional official development assistance, certification of sustainably harvested products, market-based instruments (blue bonds, biodiversity offsets, special credit lines, risk mitigation tools, payments for environmental services, impact investing) and private capital markets (debt and equity) associated with sustainable-management programs (Wabnitz and Blasiak, 2019; Clark et al., 2018; Iyer et al., 2018; Thomas, 2014; Fitzgerald et al., 2020). Traditional international philanthropy will continue to play an important role in financing the climate agenda, specifically through multilateral funds that were established to support adaptation projects, such as the Least Developed Countries Fund, the Special Climate Change Fund, the Adaptation Fund, and the Green Climate Fund (Wabnitz and Blasiak, 2019). There are, therefore, opportunities to improve on current Blue carbon mechanisms, including better stakeholder engagement, access to private sector and targeted use of public and philanthropic funding to subsidize demonstration projects, reduce financial risk, and promote high co-benefit projects.

\section{Conclusions}

This study provided an updated estimate of the area of remaining and deforested mangroves in the world and national-level estimations of carbon break-even prices needed to support mangrove conservation and restoration. These results combined with the literature review show that protecting mangroves through blue carbon programs is a viable option as long as soil carbon is accounted for, spatial variations are acknowledged, sustainable management is allowed and the stakeholders participation is assured. The diverse socio-economic and environmental contexts in which mangroves are located, requires a portfolio of solutions to effectively promote its conservation and restoration (Thompson and Friess, 2019). The biophysical and social context of mangroves, may favour the implementation of participatory small-scale programs as well as the combination of carbon-based mechanisms and sustainable management systems.

We estimated that relatively low carbon prices can support the conservation and restoration of mangroves. However, in several contexts carbon-finance alone won't be able to compete with high opportunity costs related to alternative land-uses such as high-yield aquaculture. While large-scale analyses estimate feasible carbon break-even prices (Siikamäki et al., 2012; this study), local-scale case studies show the complexity of PES schemes underlining the importance of other ecosystem services beyond carbon, and the need to incorporate sustainable management within such schemes. Local variations in land opportunity costs and people's needs must be better understood and estimated for the successful implementation of blue carbon programs. In a setting where inhabitants can combine PES programs based on multiple ecosystem services with sustainable management of one or more products, PES can offer advantages over conventional land uses while fostering local development and increasing societal resilience (e.g. Thompson et al., 2014; Romañach et al., 2018).

In sum, our study supports that (i) the large carbon stocks in mangroves make PES mechanisms cheaper than in terrestrial forest ecosystems, (ii) large variations in the opportunity costs of mangrove conservation require context-dependent solutions (iii) high land opportunity costs may hinder the implementation of larger-scale blue carbon schemes in many regions (but a better understanding of variation in costs is still needed), (iv) incorporating other ecosystem services 
and sustainable management practices can significantly increase the payed prices and therefore the attractiveness of PES programs to dwellers. The maps produced in this study are available upon request, and could be of great use for modelling and planning of blue carbon programs at national and international levels. By combining blue carbon mechanisms and co-benefits, mangrove conservation and restoration programs can promote significant benefits for local peoples while attaining high global benefits for climate mitigation.

Supplementary data to this article can be found online at https:// doi.org/10.1016/j.ecolecon.2020.106758.

\section{Declaration of Competing Interest}

The authors declare that they have no known competing financial interests or personal relationships that could have appeared to influence the work reported in this paper.

\section{Acknowledgements}

We thank Dr. Stuart Hamilton for making his dataset freely available and for kindly assisting its access and interpretation. We also thank Vinicius Pacheco and Leonardo Geluda for their contribution in the discussion. This work was conducted under work package 5 'Data Synthesis and Management of Marine and Coastal Carbon' (C6090, NE/ K001914/1) of the Shelf Sea Biogeochemistry program jointly funded by the National Environment Research Council (NERC) and the Department for Environment, Food and Rural Affairs (Defra) of the United Kingdom. The views expressed are those of the authors and do not necessarily represent those of NERC or Defra. The sponsor had no involvement in the study design, in the collection, analysis and interpretation of data, in the writing of the report or in the decision to submit the article for publication. This article was undertaken under the Collaborative Centre for Sustainable Use of the Seas.

\section{References}

Ajonina, G.N., Eyabi, G.D., 2002. Saving Cameroon's Mangroves through Improved Fish Smoking Houses: Cameroon Wildlife Conservation Society's Community-Based Approaches in Douala-Edea Mangroves. Mangrove Action Project, Los Angeles, USA.

Alcorn, J., 2010. Getting REDD Right: Best Practices that Protect Indigenous peoples' Rights and Enhance Indigenous Livelihoods. Research Report. Inter-American Development Bank, Washington, DC, USA.

Alongi, D.M., 2012. Carbon sequestration in mangrove forests. Carbon Manage. 3 (3), 313-322.

Alongi, D.M., 2014. Carbon cycling and storage in mangrove forests. Annu. Rev. Mar. Sci. 6, 195-219.

Alongi, D.M., de Carvalho, N.A., 2008. The effect of small-scale logging on stand characteristics and soil biogeochemistry in mangrove forests of Timor Leste. For. Ecol. Manag. 225, 1359-1366.

Atwood, T.B., Connolly, R.M., Almahasheer, H., Carnell, P.E., Duarte, C.M., Ewers Lewis, C.J., Irigoien, X., Kelleway, J.J., Lavery, P.S., Macreadie, P.I., Serrano, O., Sanders, C.J., Santos, I., Steven, A.D.L., Lovelock, C.E., 2017. Global patterns in mangrove soil carbon stocks and losses. Nat. Clim. Chang. 7, 523-528.

Barnes, M.N., 2014. Developing a Framework for Blue Carbon Payments. Master thesis Master of Environmental Management degree in the Nicholas School of the Environment of Duke University, pp. 50.

Bayraktarov, E., Saunders, M.I., Abdullah, S., Mills, M., Beher, J., Possingham, H.P., Mumby, P.J., Lovelock, C.E., 2016. The cost and feasibility of marine coastal restoration. Ecol. Appl. 26 (4), 1055-1074.

Bouillon, S., Rivera-Monroy, V.H., Twilley, R.R., Kairo, J.G., 2009. Mangroves. In: Laffoley, D., Grimsditch, G. (Eds.), The Management of Natural Coastal Carbon Sinks. IUCN, Gland, Switzerland.

Chong, V.C., 2006. Sustainable utilization and management of mangrove ecosystems of Malaysia. Aquat. Ecosyst. Health Manag. 9 (2), 249-260.

Chowdhury R., R., Uchida, E., Chen, L., Osorio, V., Yoder, L., 2017. Chapter 9: Anthropogenic drivers of mangrove loss: Geographic patterns and implications for livelihoods. Mangrove ecosystems: A global biogeographic perspective - Structure, function and services. Springer Publishing Company, New York, pp. 275-300.

Clark, R., Reed, J., Sunderland, T., 2018. Bridging funding gaps for climate and sustainable development: pitfalls, progress and potential of private finance. Land Use Policy 71, 335-346.

Corbera, E., Brown, K., Adger, N., 2007. The equity and legitimacy of markets for ecosystem services. Dev. Chang. 38 (4), 587-613.

Cormier-Salem, M.C., Panfili, J., 2016. Mangrove reforestation: greening or grabbing coastal zones and deltas? Case studies in Senegal. Afr. J. Aquat. Sci. 41 (1), 89-98. Donato, D.C., Kauffman, J.B., Murdiyarso, D., Kurnianto, S., Stidham, M., Kanninen, M., 2011. Mangroves among the most carbon-rich forests in the tropics. Nat. Geosci. 4, 293-297.

Duarte, C.M., Middelburg, J., Caraco, N., 2005. Major role of marine vegetation on the oceanic carbon cycle. Biogeosciences 2 (1), 1-8.

ESA CCI, 2015. available at. https://www.esa-landcover-cci.org/?q=node/158.

Eyabi, G.D., 1995. Traditional fish smoking in Cameroon. In: Teutscher, F., Tall, A., Jallow, A.M. (Eds.), Workshop on Seeking Improvements in Fish Technology in West Africa. Technical Report 6.

Feka, N.Z., Manzano, M.G., 2008. The implications of wood exploitation for fish smoking on mangrove ecosystem conservation in the south West Province, Cameroon. Tropical Conserv. Sci. 1, 222-235.

FAO, 2015. Global Forest Resources Assessment 2015. FAO Forestry Paper No1. UN Food and Agriculture Organization, Rome. http://www.fao.org/forest-resourcesassessment/past-assessments/fra-2015/en/.

Feka, N.Z., Chuyong, G.B., Ajonina, G.N., 2009. Sustainable utilization of mangroves using improved fish-smoking systems: a management perspective from the DoualaEdea wildlife reserve, Cameroon. Tropical Conserv. Sci. 2 (4), 450-468.

Fitzgerald, T., Higgins, P., Quilligan, E., Sethi, S., Puente, J., 2020. Catalyzing fisheries conservation investment. Front. Ecol. Environ. https://doi.org/10.1002/fee.2147.

Giri, C., Ochieng, E., Tieszen, L.L., Zhu, Z., Singh, A., Loveland, T., Masek, J., Duke, N., 2011. Status and distribution of mangrove forests of the world using earth observation satellite data. Glob. Ecol. Biogeogr. 20, 154-159.

Hamilton, S.E., Casey, D., 2016. Creation of a high spatio-temporal resolution global database of continuous mangrove forest cover for the 21st century (CGMFC-21). Glob. Ecol. Biogeogr. 25 (6), 729-738.

Hamilton, S.E., Friess, D.A., 2018. Global carbon stocks and potential emissions due to mangrove deforestation from 2000 to 2012. Nat. Clim. Chang. 8, 240-244.

Hansen, M.C., Potapov, P.V., Moore, R., Hancher, M., Turubanova, S.A., Tyukavina, A., Thau, D., Stehman, S.V., Goetz, S.J., Loveland, T.R., Kommareddy, A., Egorov, A. Chini, L., Justice, C.O., Townshend, J.R.G., 2013. High-resolution global maps of 21st-century forest cover change. Science 342 (6160), 850-853.

Hanson, C., Buckingham, K., DeWitt, S., Laestadius, L., 2015. The Restoration Diagnostics - Case Example: Restoration of Mangrove Forests in Vietnam. World Resources Institute.

Herr, D., von Unger, M., Laffoley, D., McGivern, A., 2017. Pathways for implementation of blue carbon initiatives. Aquatic Conserv: Mar Freshw Ecosyst. 27 (S1), 116-129.

Hoegh-Guldberg, O., Hoegh-Guldberg, H., Veron, J.E.N., Green, A., Gomez, E.D., Lough, J., King, M., Ambariyanto Hansen, L., Cinner, J., Dews, G., Russ, G., Schuttenberg, H.Z., Peñaflor, E.L., Eakin, C.M., Christensen, T.R.L., Abbey, M., Areki, F., Kosaka, R.A., Tewfik, A., Oliver, J., 2009. The Coral Triangle and Climate Change: Ecosystems, People and Societies at Risk. WWF Australia, Brisbane.

IIASA/FAO, 2012. Global Agro-Ecological Zones (GAEZ v3.0). IIASA, Laxenburg, Austria and FAO, Rome, Italy.

Iyer, V., Mathias, K., Meyers, D., Victurine, R., Walsh, M., 2018. Finance Tools for Coral Reef Conservation: A Guide. Wildlife Conservation Society and Conservation Finance Alliance, pp. 71.

Kauffman, J.B., Heider, C., Norfolk, J., Payton, F., 2014. Carbon stocks of intact mangroves and carbon emissions arising from their conversion in the Dominican Republic. Ecol. Appl. 24 (3), 518-527.

Kauffman, J.B., Trejo, H.H., Garcia, M.D.C.J., Heider, C., Contreras, W.M., 2016. Carbon stocks of mangroves and losses arising from their conversion to cattle pastures in the Pantanos de Centla, Mexico. Wetl. Ecol. Manag. 24 (2), 203-216.

Lal, P., 2003. Economic valuation of mangroves and decision-making in the Pacific. Ocean Coast. Manag. 46, 823-844.

Malik, Abdul, Fensholt, Rasmus, Mertz, Ole, 2015. Economic Valuation of Mangroves for Comparison with Commercial Aquaculture in South Sulawesi, Indonesia. Forests 6, 3028-3044. https://doi.org/10.3390/f6093028.

McLeod, E., Chmura, G.L., Bouillon, S., Salm, R., Björk, M., Duarte, C.M., Lovelock, C.E., Schlesinger, W.H., Silliman, B.R., 2011. A blueprint for blue carbon: toward an improved understanding of the role of vegetated coastal habitats in sequestering $\mathrm{CO}_{2}$. Front. Ecol. Environ. 9 (10), 552-560.

Murdiyarso, D., Purbopuspito, J., Kauffman, J.B., Warren, M.W., Sasmito, S.D., Donato, D.C., Manuri, S., Krisnawati, H., Taberima, S., Kurnianto, S., 2015. The potential of Indonesian mangrove forests for global climate change mitigation. Nat. Clim. Chang. 5, 1089-1092.

Murray, B.C., Pendleton, L., Jenkins, W.A., Sifleet, S., 2011. Green Payments for Blue Carbon Economic Incentives for Protecting Threatened Coastal Habitats. Nicholas Institute for Environmental Policy Solutions, Duke University.

Ndour, N., Dieng, S.D., Fall, M., 2011. Rôles des mangroves, modes et perspectives de gestion au Delta du Saloum (Sénégal). Vertigo 11 (3).

Powell, N., Osbeck, M., Sinh, B.T., 2011a. Mangrove Restoration and Rehabilitation for Climate Change Adaptation in Vietnam. World Resources Report Case Study. World Resources Institute, Washington. DC.

Powell, N., Gerger Swartling, A., Hoang, H.M., 2011b. Rural development in Vietnam. In: Powell, N., Gerger Swartling, A., Hoang, H.M. (Eds.), Stakeholder Agency in Rural Development Policy: Articulating Co-governance in Vietnam. Stockholm Environment Institute (SEI), Stockholm.

Richards, D.R., Friess, D.A., 2015. Rates and drivers of mangrove deforestation in Southeast Asia, 2000-2012. Proc. Natl. Acad. Sci. 133 (2), 344-349.

Robinson, S., Mason d'Croz, D., Islam, S., Sulser, T.B., Robertson, R.D., Zhu, T., Gueneau, A., Pitois, G., Rosegrant, M.W., 2015. The International Model for Policy Analysis of Agricultural Commodities and Trade (IMPACT): Model description for version 3. IFPRI Discussion Paper 1483. International Food Policy Research Institute (IFPRI), Washington, D.C. 
Romañach, S.S., DeAngelis, D.L., Koh, H.L., Li, Y., The, S.Y., Barizan, R.S.R., Zhai, L., 2018. Conservation and restoration of mangroves: global status, perspectives, and prognosis. Ocean Coast. Manag. 154, 72-82.

Sala, E., Costello, C., Dougherty, D., Heal, G., Kelleher, K., Murray, J.H., Rosenberg, A.A., Sumaila, R., 2013. A general business model for marine reserves. PLoS One 8 (4).

Sanderman, J., Hengl, T., Fiske, G., Solvik, K., Adame, M.F., Benson, L., Bukoski, J.J., Carnell, P., Cifuentes-Jara, M., Donato, D., 2018. A global map of mangrove forest soil carbon at 30m spatial resolution. Environ. Res. Lett. 13.

Shastri, C.M., Sangeetha, G., Ravindranath, N.H., 2002. Dissemination of efficient Astra stove: case study of successful entrepreneur in Sirsi, India. Energy Sustain. Dev. 5, 63-67.

Siikamäki, J., Sanchirico, J.N., Jardine, S.L., 2012. Global economic potential for reducing carbon dioxide emissions from mangrove loss. Proc. Natl. Acad. Sci. 109 (36), 14369-14374.

Strassburg, B., Turner, R.K., Fisher, B., Schaeffer, R., Lovett, A., 2009. Reducing emissions from deforestation - The "combined incentives" mechanism and empirical simulations. Glob. Environ. Chang. 19 (2), 265-278. https://doi.org/10.1016/j.gloenvcha. 2008.11.004.

Strassburg, B.B.N., Rodrigues, A.S.L., Gusti, M., Balmford, A., Fritz, S., Obersteiner, M., Turner, R.K., T. M., 2012. Impacts of incentives to reduce emissions from deforestation on global species extinctions. Nat. Clim. Chang. 2 (5), 350-355. https://doi. org/10.1038/nclimate1375.

Sulser, T.B., Mason-D'Croz, D., Islam, S., Robinson, S., Wiebe, K., Rosegrant, M.W., 2015. Africa in the global agricultural economy in 2030 and 2050. In: Badiane, O. Makombe, T. (Eds.), Beyond a Middle Income Africa: Transforming African Economies for Sustained Growth with Rising Employment and Incomes. Chapter 2. ReSAKSS Annual trends and outlook report 2014. International Food Policy Research Institute (IFPRI), Washington, D.C.. http://ebrary.ifpri.org/cdm/ref/collection/ p15738coll2/id/130003.

Tai, N.V.K.T., Ngoc, P.T., Hung, L.T., Quyen Anh, N.T., 2009. Viet Nam Assessment Report on Climate Change (VARCC). Institute of Strategy and Policy on Natural Resources and Environment, Hanoi.

Thompson, B.S., Friess, D.A., 2019. Stakeholder preferences for payments for ecosystem services (PES) versus other environmental management approaches for mangrove forests. J. Environ. Manag. 233, 636-648.
Thomas, S., 2014. Blue carbon: knowledge gaps, critical issues, and novel approaches. Ecological Economics 107, 22-38.

Thompson, B.S., Clubbe, C.P., Primavera, J.H., Curnick, D., Koldewey, H.J., 2014. Locally assessing the economic viability of blue carbon: a case study from Panay Island, the Philippines. Ecosyst. Serv. 8, 128-140.

Thompson, B.S., Primavera, J.H., Friess, D.A., 2017. Governance and implementation challenges for mangrove forest payments for ecosystem services (PES): empirical evidence from the Philippines. Ecosyst. Serv. 23, 146-155.

Tri, N.H., Adger, W., Kelly, P., 1998. Natural resource management in mitigating climate impacts: the example of mangrove restoration in Vietnam. Glob. Environ. Chang. 8 (1), 49-61.

UNEP-WCMC, 2006. In the front line: shoreline protection and other ecosystem services from mangroves and coral reefs. UNEP-WCMC, Cambridge, UK, pp. 33.

Vanderklift A., M., Marcos-Martinez, R., Butler A., J.R., Coleman, M., Lawrence, A., Prislan, H., Steven, A., Thomas, S., 2019. Constraints and opportunities for marketbased and protection of blue carbon ecosystems. Marine Policy 107. https://doi.org/ 10.1016/j.marpol.2019.02.001.

Wabnitz, C., Blasiak, R., 2019. The rapidly changing world of ocean finance. Mar. Policy 107, 103526. https://doi.org/10.1016/j.marpol.2019.103526.

Walters, B.B., Rönnbäck, P., Kovacs, J.M., Crona, B., Hussain, S.A., Badola, R., Primavera, J.H., Barbier, E., Dahdouh-Guebas, F., 2008. Ethnobiology, socio-economics and management of mangrove forests: A review. Aquat. Bot. 89, 220-236.

Warren-Rhodes, K., Schwarz, A., Boyle, L.N., Albert, J., Agalo, S.S., Warren, R., Bana, A., Paul, C., Kodosiku, R., Bosma, W., Yee, D., Rönnbäck, P., Crona, B., Duke, N., 2011. Mangrove ecosystem services and the potential for carbon revenue programmes in Solomon Islands. Environ. Conserv. 38 (4), 485-496.

Warren-Thomas, E.M., Edwards, D.P., Bebber, D.P., Chhang, P., Diment, A.N., Evans, T.D., Lambrick, F.H., Maxwell, J.F., Nut, M., O' Kelly, H.J., Theilade, I., Dolman, P.M., 2018. Protecting tropical forests from the rapid expansion of rubber using carbon payments. Nat. Commun. 9 (1), 911.

Wylie, L., Sutton-Grier, A.E., Moore, A., 2016. Keys to successful blue carbon projects: lessons learned from global case studies. Mar. Policy 65, 76-84.

Yee, S., 2010. REDD and BLUE carbon: Carbon payments for mangrove conservation. In: Capstone Project - MAS Marine Biodiversity and Conservation, Available at: https:// escholarship.org/uc/item/2bc6j8pz. 